
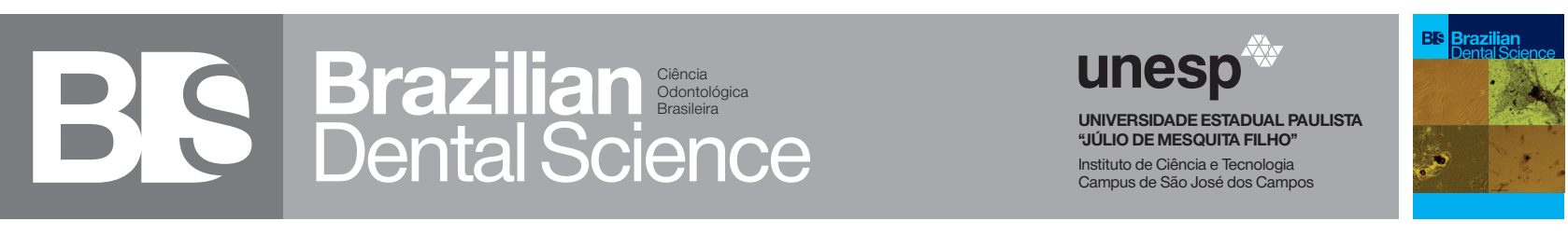

\title{
Preventive and therapeutic effects of relaxin on bisphosphonate- related osteonecrosis of the jaw: an experimental study in rats
}

Efeitos preventivos e terapêuticos da relaxina na osteonecrose da mandíbula relacionada a bisfosfonatos: um estudo experimental em ratos.

Tuba DEVELI ${ }^{1}$, Sina UCKAN ${ }^{1}$, Burak BAYRAM${ }^{2}$, Kagan DENIZ ${ }^{3}$, Saban Remzi ERDEM ${ }^{4}$, Binnaz Handan OZDEMIR ${ }^{5}$, Neslihan Bascil TUTUNCU $^{6}$, Didem BACANLI ${ }^{7}$

1 - Istanbul Medipol University - Department of Oral and Maxillofacial Surgery - İstanbul - Turkey.

2 - Baskent University - Department of Oral and Maxillofacial Surgery - Ankara - Turkey.

3 - Istanbul Baskent University - Department of Oral and Maxillofacial Surgery - Istanbul - Turkey.

4 - Baskent University Medical Faculty - Department of Pharmacology - Ankara - Turkey.

5 - Baskent University Medical Faculty - Department of Pathologhy - Ankara - Turkey.

6 - Baskent University Medical Faculty - Department of Endocrinologhy - Ankara - Turkey

7 - Baskent University Medical Faculty - Experimental Animals Breeding and Research Center - Ankara - Turkey.

\section{ABSTRACT}

Objective: Bisphosphonate-related osteonecrosis of the jaw (BRONJ) is a challenging complication of chronic bisphosphonate (BP) use. The hormone relaxin is able to induce the multistep differentiation process of human osteoclastogenesis, exhibits antifibrotic and anti-inflammatory actions, and promotes vasodilatation, wound healing, and angiogenesis. The present study aimed to evaluate the effects of relaxin in the prevention and management of BRONJ. Material and Methods: Thirty-six male Sprague Dawley rats were randomly divided into four groups. Rats in group $1(\mathrm{n}=10)$ received relaxin and BP simultaneously for 12 weeks. Rats in group $2(\mathrm{n}=10)$ received injections of BP for 12 weeks, followed by relaxin for another 12 weeks. Rats in group $3(\mathrm{n}=10)$ received only BP injections, and those in group 4 (control, $n$ $=6$ ) received only saline. Necrosis and inflammation in the rats' mandibles were evaluated as indicators of BRONJ. Results: Necrosis and inflammation were not detected in group 1 (BP + relaxin). In group 3 (BP only), incidence rates of necrosis and inflammation were $90 \%$ and $60 \%$, respectively. Conclusions: Our findings suggest that relaxin may be potently effective in preventing BRONJ and have some benefit in the treatment of existing BRONJ.

\section{KEYWORDS}

Animal model; BRONJ; Relaxin.

\section{RESUMO}

Objetivo: A osteonecrose da mandíbula relacionada ao bisfosfonato (BRONJ) é uma desafiadora complicação do uso crônico de bisfosfonato (BP). O hormônio relaxina é capaz de induzir o processo múltiplo de diferenciação da osteoclastogênese humana, exibe ações anti-fibróticas e anti-inflamatórias e promove vasodilatação, cicatrização de feridas e angiogênese. $O$ presente estudo teve como objetivo avaliar os efeitos da relaxina na prevenção e tratamento do BRONJ. Material e Métodos: Trinta e seis ratos Sprague Dawley machos foram divididos aleatoriamente em quatro grupos. Os ratos do grupo 1 ( $\mathrm{n}=10)$ receberam relaxina e BP simultaneamente por 12 semanas. Os ratos do grupo $2(n=10)$ receberam injeções de BP por 12 semanas, seguidos de relaxina por mais 12 semanas. Os ratos do grupo $3(n=10)$ receberam apenas injeções de BP e os do grupo 4 (controle, $n=6$ ) receberam apenas solução salina. Necrose e inflamação nas mandíbulas dos ratos foram avaliadas como indicadores de BRONJ. Resultados: Necrose e inflamação não foram detectadas no grupo 1 (BP + relaxina). No grupo 3 (somente BP), as taxas de incidência de necrose e inflamação foram de $90 \%$ e $60 \%$, respectivamente. Conclusões: Nossos resultados sugerem que a relaxina pode ser potentemente eficaz na prevenção do BRONJ e ter algum benefício no tratamento do BRONJ existente.

\section{PALAVRAS-CHAVE}

Modelo animal; BRONJ; Relaxina. 


\section{INTRODUCTION}

B isphosphonate (BP) - related osteonecrosis of the jaw (BRONJ) has been one of the most complex and challenging pathologies in oral and maxillofacial surgery in recent years. Management of BRONJ remains controversial, and there is no common standard treatment protocol for this disease [1].

Although the first BRONJ case was reported overa decadeago, the pathophysiology of the disease has not been fully clarified [2]. Altered bone remodeling, suppression of bone resorption, inhibition of angiogenesis, microtrauma, immunosuppression, vitamin $\mathrm{D}$ insufficiency, and soft tissue BP toxicity may be factors explaining why BRONJ develops in the jaws specifically [3-11].

BP inhibits osteoclast differentiation and function, which play a vital role in bone healing, and also increases osteoclast apoptosis, resulting in decreased bone resorption and remodeling [12-16]. In addition, BPs display anti-angiogenic activity, and studies in patients treated with BP support these data with decreased circulating VEGF levels [17-20].

Relaxin is a two-chain peptide hormone produced in the ovaries and placenta during pregnancy. This hormone relaxes the interpubic ligament, inhibits spontaneous uterine contractions, and promotes cervical softening [21,22].

The major effects of relaxin are extracellular matrix remodeling, collagen degradation, and upregulation of matrix metalloproteinases. It may also be involved in wound healing, angiogenesis, and fibrosis $[21,22]$. Recent studies showed that relaxin promotes osteoclast differentiation, activation, and stimulation [23].

The effects of relaxin on osteoclastogenesis and angiogenesis suggest its potential role as BP antagonist in bone metabolism. The aim of the present study was to evaluate the effect of relaxin in the prevention and management of BRONJ.

\section{MATERIAL AND METHODS}

This study was supported by TUBITAK (Scientific and Technological Research Council of 1001 Project no: 111S118) and approved by the Baskent University Animal Care and Ethics Committee.

Thirty-six Sprague Dawley rats were randomly divided into four groups. Rats in group 1 ( $\mathrm{n}=10)$ simultaneously received relaxin $(0.17 \mu \mathrm{g} / \mathrm{hr})$ by osmotic minipump (ALZET) and zoledronate $(0.1 \mathrm{mg} / \mathrm{kg})$ by intraperitoneal (IP) injection 3 times per week for 12 weeks. Rats in group $2(\mathrm{n}=10)$ were first administered zoledronate $(0.1 \mathrm{mg} /$ $\mathrm{kg}$ ) by IP injection 3 times per week for 12 weeks, followed by relaxin $(0.17 \mu \mathrm{g} / \mathrm{hr})$ by osmotic minipump (ALZET) for another 12 weeks. In group $3(n=10)$, rats received only zoledronate $(0.1 \mathrm{mg} / \mathrm{kg})$ IP injection for 12 weeks. Group $4(n=6)$ received sterile saline both by IP injection $(0.1 \mathrm{mg} / \mathrm{kg}, 3$ times per week) and by osmotic minipump for 12 weeks. No other interventions (e.g., steroid therapy, dental extraction) were performed on the rats in order to observe the isolated effects of the $\mathrm{BP}$ on the jaw.

\section{Surgical Procedure}

General anesthesia was achieved by intramuscular (IM) injection of $50 \mathrm{mg} / \mathrm{kg}$ ketamine (Ketalar, Pfizer, Istanbul) and 5 $\mathrm{mg} / \mathrm{kg}$ xylazine (Rompun, Bayer, Istanbul, Turkey). After placing the animal in prone position, the back was shaved, draped, and prepared. Lidocaine was administrated to provide local hemostasis. Following a $1-\mathrm{cm}$ vertical skin incision to the midline, a hemostat was used to create a pouch in which to place the osmotic minipump. After inserting the osmotic minipump, the skin was closed using resorbable sutures. Antibiotic and analgesic (enrofloxacin IM $10 \mathrm{mg} / \mathrm{kg}$ and fentanyl intravenous [IV] $0.0074 \mathrm{mg} / \mathrm{kg}$ ) were administered to all rats postoperatively. The osmotic minipumps were replaced every 4 weeks. 
The rats were killed 2 days after completing the 12-week treatment period in groups 1,3 , and 4 , and 2 days after the 24week treatment period for group 2 .

\section{Histopathological Evaluation}

The mandible of each rat was extracted for histopathological evaluation. After removing the mandible, the posterior mandible (specimen from the area under the third and first molars and above the mental foramen) was decalcified in 5\% formic acid and fixed with $10 \%$ buffered formalin solution. The specimens were embedded in paraffin blocks, from which sections were cut and stained with H\&E (hematoxylin and eosin). A senior pathologist who was blinded to the treatment conditions performed histopathologic evaluations of the sections for the presence of necrosis and inflammation. Using light microscopy under 200x magnification, numbers of necrotic and inflammatory cells per thousand cells were counted manually in the five most intensely stained areas.

\section{Statistical Analysis}

Data analysis was performed with SPSS v24 software for Windows. Statistical analysis was performed using Fisher's exact test. A difference of $\mathrm{p}<0.05$ was considered statistically significant. When a statistically significant difference was detected, post hoc pairwise analysis was conducted for each pair of groups. Statistically significant $\mathrm{p}$ value for post hoc analysis was determined as $\mathrm{p}<0.008$ using Bonferroni correction.

\section{RESULTS}

None of the rats in groups 1 and 4 showed signs of necrosis, while the incidence of necrosis was 50\% and 90\% in groups 2 and 3, respectively (Figure 1 and 2). Statistical analysis showed a significant difference in necrotic cell count among the groups ( $\mathrm{p}<0.001)$. Post hoc analysis revealed no significant difference in necrotic cell count between groups 1,2, and 4, while group 3 differed significantly from groups
1 and 4 ( $\mathrm{p}<0.001$ for both comparisons). There was no statistically significant difference in necrosis between groups 2 and $3(\mathrm{p}=0.141)$ (Table 1).
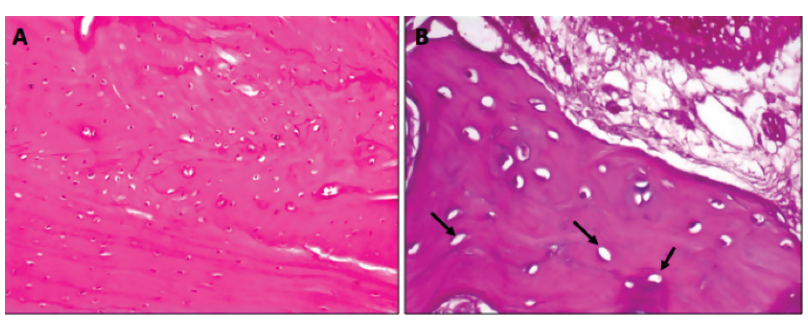

Figure 1 - (A) Appearance of bone from group 1 (simultaneous zoledronate and relaxin) with no signs of necrosis on histopathological examination. (B) Areas of local necrosis were observed in group 2 (first zoledronate, then relaxin). Lacunae without nuclei (arrow). These empty lacunae were considered necrotic areas.

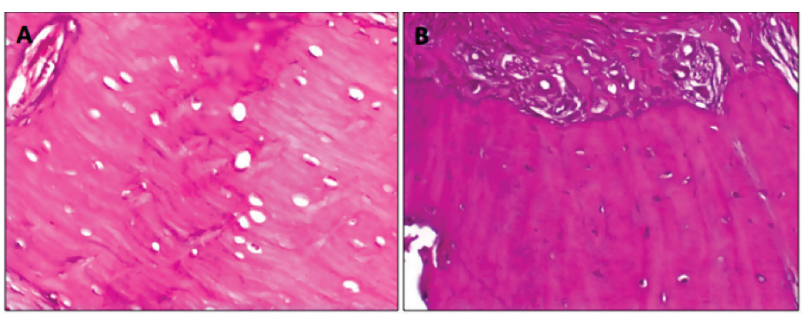

Figure 2 - (A) Common necrotic areas and numerous empty lacunae in group 3 (zoledronate only). (B) Appearance of bone from the control group (sterile saline only) with no necrotic areas on histopathological examination.

Similarly, inflammatory cells were not observed in any of the rats in groups 1 and 4 but were detected in $20 \%$ and $60 \%$ of the rats in groups 2 and 3, respectively. Statistical analysis showed a significant difference among groups $(p=0.004)$. However, post hoc pairwise analysis with a threshold of $\mathrm{p}<$ 0.008 did not yield any significant results. The lowest $\mathrm{p}$ value was 0.011 , between groups 1 and 3. Thus, the statistical significance found between groups regarding the prevalence of inflammatory cells was considered a false positive. 
Table 1 - Histopathological findings of rats under light microscopy

\begin{tabular}{|ccc|}
\hline Group & Necrotic cells, $\mathbf{n}(\%)$ & Inflammatory cells, $\mathbf{n}(\%)$ \\
\hline 1 & 0 & 0 \\
2 & $5(50)$ & $2(20)$ \\
3 & $9(90)$ & $6(60)$ \\
\hline 4 & 0 & 0 \\
\hline Fisher's & $p<0.001$ & $\mathrm{P}=0.004$ \\
Exact Test & $3-13-4$ & No intergroup differences $p>0.008$ \\
\hline Posthoc & $\mathrm{p}<0.001$ &
\end{tabular}

\section{DISCUSSION}

Bisphosphonates have been used in cancer treatment to prevent metastasis as well as in the treatment of bone metabolism disorders to prevent skeletal complications. $\mathrm{BP}$ reduces bone resorption by inhibiting osteoclast activity and differentiation. A strong correlation has been demonstrated between BP use and osteonecrosis of the jaws. Although the pathogenesis of BRONJ and its specific localization to the jaw are still not fully understood, there are many theories. These include theories that the development of necrosis in the jaw can be attributed to the high bone turnover in the jaws, presence of the microorganisms in the oral flora, inhibition of angiogenesis, and osteoclast apoptosis $[24,25]$. In this study, we also detected jaw necrosis in $90 \%$ of the rats that received highdose BP injection for 12 weeks without any dental interventions.

BRONJ dramatically influences patients' quality of life and requires immediate intervention. However, there is still no consensus regarding the management or prevention of BRONJ [25]. The American Association of Oral and Maxillofacial Surgeons (AAOMS) reported that the incidence of BRONJ $(0.8-12 \%)$ is dependent on the dose and duration of BP therapy [26]. When BRONJ is detected, risk factors likely cause or exacerbate should be determined and ideally eliminated or reduced with antibacterial mouth rinse and antibiotics followed by minimally invasive surgical treatment [27-31]. Moreover, alternative treatment modalities such as laser, growth factors, hyperbaric oxygen, PRF, and ozone therapy can be used [32-35].

BPs can accumulate in the bone and inhibit osteoclast-mediated bone resorption, resulting in reduced bone turnover at the cellular and molecular levels [36]. It is reported that BPs also depress bone blood flow and significantly decrease circulating levels of vascular endothelial growth factor, which is important in the angiogenesis process [17-20].

Recent studies have reported the effects of relaxin on bone metabolism [37-40]. BPs and relaxin have antagonistic mechanisms of action on osteoclastogenesis and angiogenesis. While BPs inhibit osteoclastogenesis and angiogenesis, relaxin stimulates these processes. Therefore, we aimed to evaluate the effects of relaxin on BRONJ. To the best of our knowledge, our study is the first to examine the preventive and therapeutic effects of relaxin on BRONJ.

According to our results, necrosis and inflammation occurred in $90 \%$ and $60 \%$ of rats given only BP, compared to none of the rats in the group given relaxin and BP simultaneously. Statistical comparison of these two groups confirmed significant differences in terms of necrosis and inflammation. These results suggest that relaxin may be potently effective in the prevention of BRONJ.

While systemic administration of the relaxin completely prevented BRONJ development in our study, administration of relaxin after the development of BRONJ resulted in partial improvement that did not reach statistical significance. Its preventive action is evidence of the antagonistic effect of relaxin on bone and angiogenesis in the pathogenetic mechanism of BRONJ. This study evaluated the effectiveness of systemic relaxin; considering this antagonistic action, local administration also warrants further investigation. 
Relaxin is an insulin superfamily polypeptide hormone secreted from the ovaries (especially during puberty) that relaxes the interpubic ligament and facilitates birth. It was later found to also be secreted by the prostate in men. The major actions of relaxin include mediation of extracellular matrix remodeling, collagen degradation, and matrix metalloproteinase upregulation, as well as playing a role in fibrosis, wound healing, angiogenesis, and response to infarction. Relaxin is also a cardiotropic hormone that regulates the function of platelets and mast cells [37,39].

Studies have shown that relaxin induces osteoclast differentiation and activation, and affects osteoclastogenesis with the same timing as classical osteoclast stimulators such as RANKL, M-CFS, and PTH $[39,40]$. Furthermore, relaxin exhibits antifibrotic and anti-inflammatory actions and promotes vasodilatation, wound healing, and angiogenesis [41].

We have shown that the simultaneous use of relaxin with $\mathrm{BP}$ had a preventive effect against BRONJ. However, the regression of existing BRONJ with relaxin was not statistically significant. This should be investigated in larger series of animals.

BRONJ was most pronounced in the rats which were treated with only BP (group 3 ). It should be noted that high doses of BP were administered to the rats in our study. In clinical practice, BPs are used in relatively lower doses. Therefore, we can speculate that the preventive effect of relaxin against BRONJ would be more efficient in the practice of oral surgery.

\section{CONCLUSION}

Systematic administration of relaxin had a significant preventive effect on BRONJ development. Although relaxin was not found to have significant therapeutic effect in this study, the number of rats was small. Therefore, further studies are needed to corroborate the treatment effectiveness and clinical use of this protocol in humans.

\section{REFERENCES}

1. Advisory Task Force on Bisphosphonate-Related Ostenonecrosis of the Jaws, American Association of Oral and Maxillofacial Surgeons. American Association of Oral and Maxillofacial Surgeons position paper on bisphosphonate-related osteonecrosis of the jaws. J Oral Maxillofac Surg. 2007 Mar;65(3):369-76.

2. MarxRE. Pamidronate (Aredia) and zoledronate (Zometa) induced avascular necrosis of the jaws: a growing epidemic. J Oral Maxillofac Surg. 2003 Sep;61(9):1115-7

3. Reid IR, Bolland MJ, Grey AB. Is bisphosphonate-associated osteonecrosis of the jaw caused by soft tissue toxicity? Bone. 2007 Sep;41(3):318-20.

4. Bamias A, Kastritis E, Bamia C, Moulopoulos LA, Melakopoulos I,Bozas G, Koutsoukou V, Gika D, Anagnostopoulos A, Papadimitriou C, Terpos E,Mimopoulos MA. Osteonecrosis of the jaw in cancer after treatment with bisphosphonates: incidence and risk factors. J Clin Oncol. 2005 Dec; 23(34):8580-7.

5. Bi Y, Gao Y, Ehirchiou D, Cao C, Kikuiri T, Le A, Shi S, Zhang L. Bisphosphonates cause osteonecrosis of the jaw-like disease in mice. Am JPathol. 2010 Jul;:177(1):280-90.

6. Hokugo A, Christensen R, Chung EM, Sung EC, Felsenfeld AL, Sayre JW, Garrett N, Adams JS, Nishimura I. Increased prevalence of bisphosphonate-related osteonecrosis of the jaw with vitamin D deficiency in rats. J Bone Miner Res. 2010. Jun; 25(6):1337-49.

7. Mortensen M, Lawson W, Montazem A. Osteonecrosis of the jaw associated with bisphosphonate use:Presentation of seven cases and literature review. Laryngoscope. 2007. Jan;117(1):30-4.

8. Sonis ST, Watkins BA, Lyng GD, Lerman MA, Anderson KC. Bony changes in the jaws of rats treated with zoledronic acid and dexamethasone before dental extractions mimic bisphosphonate-related osteonecrosis in cancer patients. Oral Oncol. 2009 Feb; 45(2):164-72.

9. Mehrotra B, Ruggiero S. Bisphosphonate complications including osteonecrosis of the jaw. Hematology Am Soc Hematol Educ Program. 2006 Jan;2006(1):356-60

10. Ruggiero SL, Fantasia J, CarlsonE. Bisphosphonate-related osteonecrosis of the jaw: background and guidelines for diagnosis, staging and management. Oral Surg Oral Med Oral Pathol Oral Radiol Endod. 2006 0ct;102(4):433-41.

11. Wood J, Bonjean K, Ruetz S, Bellahcène A, Devy L, Foidart JM, Castronovo V,Green JR. Novel antiangiogenic effects of the bisphosphonate compound zoledronic acid. J Pharmacol Exp Ther.2002 Sep;302(3):1055-61.

12. Baron R, FerrariS, Russell RG. Denosumab and bisphosphonates: different mechanisms of action and effects. Bone. 2011 Apr;48(4):677-92.

13. Lacey DL, Boyle WJ, Simonet WS, Kostenuik PJ, Dougall WC, Sullivan JK, San Martin J,Dansey R. Bench to bedside: eluci- dation of the OPG-RANK-RANKL pathway and the development of denosumab. Nat Rev Drug Discov. 2012 May;11(5):401-19.

14. Russell RG, Watts NB, Ebetino FH, Rogers MJ. Mechanisms of action of bisphosphonates: similarities and differences and their potential influence on clinical efficacy. Osteoporos Int. 2008 Jun;19(6):733-59.

15. Roelofs AJ, Thompson K, Gordon S, Rogers MJ. Molecular mechanisms of action of bisphosphonates: current status. Clin Cancer Res. 2006 0ct;12(20 part2):6222-30

16. Russell RG, Rogers MJ. Bisphosphonates: from the laboratory to the clinic and back again. Bone. 1999 Jul;25(1):97-106. 
17. Allen MR, Burr DB. The pathogenesis of bisphosphonate-related osteonecrosis of the jaw: so many hypotheses, so few data. J Oral Maxillofac Surg.2009 May;67(5 Suppl):61-70.

18. Landesberg R, Woo V,Cremers S, Cozin M, MaroltD, Vunjak-Novakovic G, Kousteni S, Raghavan S. Potential pathophysiological mechanisms in osteonecrosis of the jaw. Ann NY Acad Sci. 2011Feb;1218:62-79.

19. Yamashita J,McCauley LK. Antiresorptives and osteonecrosis of the jaw. J Evid Based DentPract. 2012Sep;12(3):233-47.

20. Kim HK. Introduction to osteonecrosis of the femoral head (OFH) and osteonecrosis of the jaw (ONJ). J Musculoskelet Neuronal Interact. 2007 Oct-Dec;7(4):350-3.

21. Bathgate RA, Ivell R, Sanborn BM, Sherwood OD, Summers RJ. International Union of Pharmacology LVIl: recommendations for the nomenclature of receptors for relaxin family peptides. Pharmacol Rev. 2006 Mar;58(1):7-31.

22. Bathgate RA, Ivell R, Sanborn BM, Sherwood OD, Summers RJ. Receptors for relaxin family peptides. Ann N Y Acad Sci. 2005 May;1041:61-76.

23. Moon JS, Kim SH, Oh SH, Jeong YW, Kang JH, Park JC, Son HJ, Bae S, Park Bl, Kim MS, Koh JT, Ko HM. Relaxin augments BMP-2-induced osteoblast differentiation and bone formation. J Bone Miner Res. 2014 Jul;29(7):1586-96.

24. Major P,Lortholary A, Hon J, Abdi E, Mills G, Menssen HD, YunusF,Bell R, Body J, Quebe-Fehling E, Seaman J.Zoledronic acid is superior to pamidronate in the treatment of hypercalcemia of malignancy; a pooled analysis of two randomized, controlled clinical trials. JClin Oncol. 2001 Jan;19(2):558-67.

25. Goodday RH. Preventive strategies for patients at risk of medication-related osteonecrosis of the jaw. Oral Maxillofacial Surg Clin North Am. 2015 Nov;27(4):527-36.

26. Ruggiero SL, Dodson TB, Assael LA, Landesberg R, Marx RE, Mehrotra B; American Association of Oral and Maxillofacial Surgeons. American Association of Oral and Maxillofacial Surgeons position paper on bisphosphonate-related osteonecrosis of the jaws-2009 update.J Oral Maxillofac Surg.2009 May;67(5):2-12.

27. Ruggiero SL, Mehrotra B, Rosenberg TJ, Engroff SL Osteonecrosis of the jaws associated with the use of bisphosphonates: a review of 63 cases. J Oral Maxillofac Surg. 2004 May;62(5):527-34.

28. Greenberg MS. Intravenous bisphosphonates and osteonecrosis. Oral Surg Oral Med Oral Pathol Oral Radiol Endod. 2004 Sep;98(3):259-60.
29. Gibbs SDJ, O'Grady J, Seymour JF, Prince HM. Bisphosphonate-induced osteonecrosis of the jaw requires early detection and intervention. Med J Aust. 2005 Nov;183(10):549-50.

30. Marx RE, Sawatari Y,Fortin M, Broumand V. Bisphosphonate-induced exposed bone (osteonecrosis/osteopetrosis) of the jaws: risk factors, recognition, prevention, and treatment. J Oral Maxillofac Surg.2005 Nov;63(11):1567-75.

31. Melo MD, Obeid G. Osteonecrosis of the jaws in patients with a history of receiving bisphosphonate therapy: strategies for prevention and early recognition. J Am DentAssoc. 2005 Dec;136(12):1675-81.

32 Freiberger JJ, Padilla-Burgos R, Chhoeu AH, Kraft KH, Boneta 0, Moon RE, Piantadosi CA. Hyperbaric oxygen treatment and bisphosphonate-induced osteonecrosis of the jaw: a case series. J Oral Maxillofac Surg.2007 65(7):1321-7.

33. Pautke C, Bauer F, Tischer T, Kreutzer K, Weitz J, Kesting M, HölzleF, Kolk A, Stürzenbaum SR, Wolff KD. Fluorescence- guided bone resection in bisphosphonate- associated osteonecrosis of the jaws. J Oral Maxillofac Surg. 2009 Mar;67(3):471-6.

34. Vescovi P,Merigo E, Meleti M, Manfredi M. Bisphosphonate-associated osteonecrosis (BON) of the jaws: a possible treatment? J Oral Maxillofac Surg 2006 Sep;64(9):1460-2.

35. Soydan S, Uckan S. Management of bisphosphonate-related osteonecrosis of the jaw with a platelet-rich fibrin membrane:technical report. J Oral Maxillofac Surg. 2014 Feb; 72(2) :322-6.

36. Drake M, Clarke B, Khosla S. Bisphosphonates: Mechanism of Action and Role in Clinical Practice. Mayo Clin Proc. 2008 September;83(9):1032-1045.

37. Moon J,Kim S, Oh S, Jeong Y, Kang J,Park J, Son H, Bae S, Park B, Kim M, Koh $\mathrm{J}, \mathrm{Ko}$ HM. Relaxin augments BMP-2-Induced osteoblast differentiation and bone formation. JBone Miner Res. 2014 Jul;29(7):1586-96.

38. Duerte C, Kobayashi Y,Kawamoto T,Moriyama K. Relaxin enhances differentiation and matrix mineralization through Relaxin/insulin-like family peptide receptor 2 (Rxfp2) in MC3T3-E1 cells in vitro. Bone. 2014 Aug;65;92-101.

39. Facciolli A, Ferlin A, Gianesello L, Pepe A, Foresta C. Role of relaxin in human osteoclastogenesis. Ann N Y Acad Sci. 2009 Apr;1160:221-5.

40. Ferlin A, Pepe A, Facciolli A, Gianesollo L, Foresta C. Relaxin stimulates osteoclast differantation and activation. Bone.2010 Feb;46(2):504-13.

41. Chow BSM, Chew EGY,Zhao C, Bathgate RAD, Hewitson TD, Samuel C. Relaxin Signals through a RXFP1-pERK-nNOS-NO-cGMP-Dependent Pathway to Up-Regulate Matrix Metalloproteinases: The Additional Involvement of iNOS. PLoS One. 20127(8): e42714.

Tuba Develi, DDS, PhD

(Corresponding address)

İstanbul Medipol University, Department of Oral and Maxillofacial

Surgery, İstanbul, Turkey

Date submitted: 2019 Aug 08

E-mail: tdeveli@medipol.edu.tr 